The Turkish Online Journal of Design, Art and Communication - TOJDAC

ISSN: 2146-5193, April 2019 Volume 9 Issue 2, p. 191-201

\title{
A STUDY ON MEASURING COMPLEXITY IN MUQARNAS PATTERNS
}

\author{
Orkan Zeynel GÜZELCi \\ İstanbul Kültür Üniversitesi, Türkiye \\ o.guzelci@iku.edu.tr \\ orcid.org/0000-0002-5771-4069 \\ Sema ALACAM \\ İstanbul Teknik Üniversitesi, Türkiye \\ semosphere@gmail.com \\ orcid.org/0000-0002-5979-3282
}

\begin{abstract}
Muqarnas forms and patterns carry a high level of spatial, structural, geometrical, and topological complexity. Having a high-level complexity and its definition through simple geometrical and mathematical relations makes muqarnas rich source of information content. By using entropy, which is one of the most important components of information theory, the complexities of built environments or building elements in various scales can be measured. Within the scope of this study, three entropybased methods were used to calculate the complexities of the muqarnas patterns located in the portal of the Buruciye Medrese, which was built in the Seljuk Period in Sivas. In this study, only shape factor was chosen among various factors for calculation and a layer-based representation was used to represent muqarnas patterns. As a result of the study, it was seen that calculated entropy value changed when the muqarnas pattern had different levels of detail. In addition, it was observed that the entropy values of the discrete layers differed from each other.
\end{abstract}

Keywords: Muqarnas Pattern, Complexity, Shape Entropy, Information Theory, Islamic Architecture

\section{MUKARNAS ÖRÜNTÜLERININ KARMAŞIKLIĞININ ÖLÇÜLMESİ ÜZERINE BİR ÇALIŞMA}

\section{ÖZ}

Mukarnaslar formları ve örüntüleri uzamsal, yapısal, geometrik ve topolojik bağlamda yüksek derecede karmaşıklık içermektedir. Yüksek derecede karmaşıklığın basit geometrik ve matematiksel ilişkilerle tarif edilebilmesi mukarnasları zengin bir içerik kaynağı olduğunu göstermektedir. Enformasyon teorisinin en önemli bileşenlerinden olan entropi kullanılarak yapılı çevrelerin veya çeşitli ölçeklerde yapı elemanlarının karmaşıklıkları ölçülebilmektedir. Bu çalışma kapsamında geliştirilen entropi tabanlı 3 yöntemle Selçuklu Dönemi'nde Sivas'ta inşa edilmiş Buruciye Medresesi'nin portalinde yer alan mukarnasın karmaşık değerleri hesaplanmıştır. Mukarnasın karmaşıklığı sadece biçim faktörü üzerinden hesaplanmıştır. Çalışmanın sonucunda mukarnas örüntüsünün farklı detay seviyelerinde ele alınmasıyla entropi değerinin değiştiği görülmüştür. Ayrıca, mukarnası oluşturan katmanlarına bakıldığında ayrık katmanların entropi değerlerinin birbirinden farkl1laştı̆̆g görülmüştür.

Anahtar Kelimeler: Mukarnas Örüntüsü, Karmaşıklık, Biçim Entropisi, Enformasyon Teorisi, İslam Mimarisi 
The Turkish Online Journal of Design, Art and Communication - TOJDAC ISSN: 2146-5193, April 2019 Volume 9 Issue 2, p. 191-201

\section{INTRODUCTION}

Discussions on calculation of the complexities of the built environments and artifacts according to their physical properties has been the subject of studies in many fields such as psychology, architecture and art since the 1960's. In existing literature, built environments and artifacts are considered as information sources which have varying complexity levels. According to Salingaros (2014), information sources may have properties of two different types of complexity as "organized" and "disorganized". Organized complexity consists of internal organizations and the system sustains itself through an "order" arising from these internal organizations. On the other hand, disorganized complexity lacks internal organization and order, and as a result, there occurs randomness in the system (Salingaros, 1999; 2014). In other words, the monotony may arise as a result of the information source being very ordered and the complexity in the absence of any order can lead to chaos. Of significance is the concept of entropy, an important component of Shannon's information theory introduced in 1948, has the ability to measure the complexity, disorder and uncertainty of objects. Standish (2008) classified complexity in two different ways as "quality" and "quantity". Where complexity is considered as a quantity; information theory and entropy can be used to calculate complexity. Simply, entropy measurements can be made on one-dimensional strings which consist of letters, numbers or symbols. While the entropy measurement is performed on the string, methods of identifying the types of discrete parts and the number of repetitions of the types are followed.

The entropy values of built environments and artifacts can be calculated according to their measurable physical properties (Arnheim, 1971; Krampen, 1979; Stamps, 1998; Stamps, 2004; Crompton, 2012). When examining the internal structure of physical properties, an artefact with low complexity can contain a high degree of visual complexity. Conversely, it can be said that internal physical complexity is independent of the visual complexity of the system; this is directly related to the appearance of the system. Furthermore, the internal relations among the sub-parts that form the whole can create complex organizations. It is possible to observe similar cases in muqarnas, which are historical architectural archetypes. Muqarnas patterns can be considered as a rich source of geometrical, spatial and topological relations. This study focuses on the quantitative features of muqarnas patterns such as repetition, element number, element scale, symmetry which have potential to lead both ordered and disordered complexity

\section{Aim and Scope}

The grassroot efforts to identifying muqarnas patterns with mathematics, geometry and algorithms date back to the work of Al-Kashi in the 15th century. The general objective of this study is to gain a deeper understanding of implicit and explicit geometrical properties and orders of muqarnas through measuring the structural or physical complexity of muqarnas patterns. Further, the main objective of this study is to develop methods which can be used to measure complexities through coding muqarnas patterns with different representations. This study differs from the previous muqarnas studies by bringing muqarnas studies and entropy measurements together in a combined method. The scope of this study examines the muqarnas patterns of a $13^{\text {th }}$ century building Buruciye Medrese which is in Sivas, Turkey. Initially, the pattern of muqarnas in the portal of Buruciye Medrese was investigated in three different detail levels and their subparts were identified through drawings of Özdural (1991). Then, upon coding the muqarnas pattern with the help of the letters, the entropy values of the patterns were calculated by identifying the shape types, counting the total number of shapes and the repetition numbers of each shape type. In this study, only shape factor was taken into consideration while calculating the entropy of muqarnas patterns. Shape entropy was used as the calculation method, which was introduced and used in a variety of ways in previous studies (Crompton, 2012; Stamps, 2012). 


\section{MUQARNAS PATTERNS}

The transition from a cubic volume to a circular shell throughout history has been a challenging study topic not only for craftsmen and artists but also for scientists interested in mathematics and geometry. As a result, archetypes such as domes, muqarnas, pendentives and Turkish Triangles have emerged. Muqarnas, as an architectural transition element from two-dimensional geometry to three-dimensional forms, can be traced back to the 10th century (Figure 1). Muqarnas formations have been observed in different scales on many building elements such as entrance portals, cornices, mihrab niches, domes, and minarets. It is observed that the rich geometries, in both two-dimensional patterns and threedimensional forms, were obtained as a result of the application of Muqarnas in different geographies for centuries. Al Kashi, a pioneer, has completed and presented a resource of the building of muqarnas in 1427 in his manuscript, which is of significance. This manuscript introduced muqarnas elements geometries such as square, rhombus, half-rhombus, almond, small biped, jug, large biped and barley kernel; and characteristics of muqarnas elements such as units, cells, and filling elements. In addition, detailed instructions for artisans such as mathematical definitions, construction rules, geometrical parameters such as angles, dimensions and topologies were also provided within the manuscript ( $\mathrm{Al}$ Kashi, 1977; Özdural, 2000). The information provided by Al-Kashi has continued to be a guide discussed in many studies published after 2000 (Dold Samplonius \& Harmsen, 2005; Harmsen, 2006; Hensel, 2008).
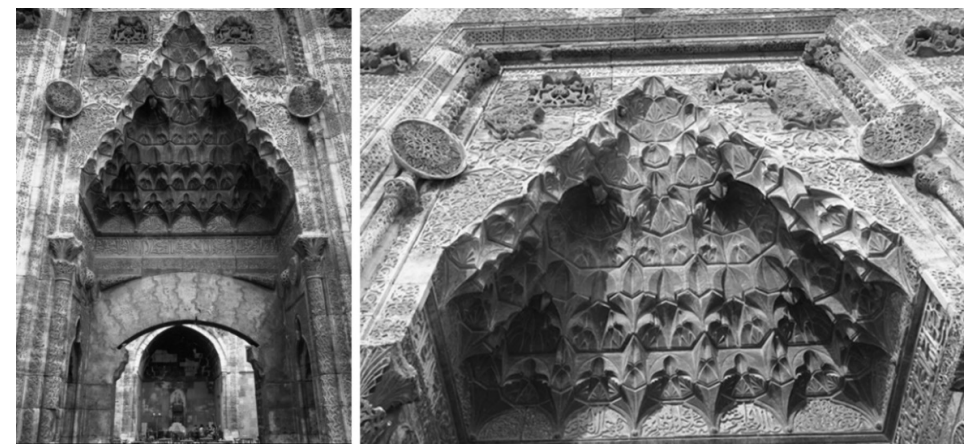

Figure 1: Images of Muqarnas from the Entrance Portal of Buruciye Medrese, Sivas (Url-1)

In traditional way of making, beginning with a two-dimensional pattern and projecting this pattern into three-dimensional form is crucial. Non-interlocking three-dimensional forms are used to construct the elevated third-dimensional muqarnas based on referenced two-dimensional muqarnas pattern drawing (Alaçam et al. 2017). In this sense, a muqarnas organization and its projection onto two-dimensional planar surface carries a high level of spatial (Özdural, 1990), structural (Notkin, 1995; DoldSamplonius \& Harmsen, 2015), geometrical (Notkin, 1995), and topological (Alaçam et al. 2017) complexity. On the contrary, it is possible to achieve complexity in a muqarnas application based on simple assumptions and rules. This tension between high-level complexity and its reducibility into simple geometrical and mathematical relations makes muqarnas rich sources of information content. Additionally, applying operations such as induction, deduction, inflation, and deflation to muqarnas patterns allow for many potential research inquiries and findings on muqarnas patterns and forms. Prior to providing an explanation on the complexity measurement methods of the muqarnas patterns, the following related concepts used in the study are explained: shape, element, layer, string, and level of detail.

\section{Related Concepts}

- Shape: In the scope of this study shape refers to two-dimensional representations which are achieved from the projection of three-dimensional muqarnas elements onto planar surfaces. Al 
The Turkish Online Journal of Design, Art and Communication - TOJDAC

ISSN: 2146-5193, April 2019 Volume 9 Issue 2, p. 191-201

Kashi (1977) has also defined specific shapes such as, "rhombus", "half rhombus", "biped", which have been frequently used in muqarnas studies.

- Element: The term element here refers to the cell-like closed-polygons obtained by the projection of three-dimensional muqarnas geometry onto two-dimensional surfaces. Elements used to build muqarnas forms and have non-overlapping and non-intersecting characteristics.

- Layer: In the scope of this study, the term layer is used for the plan projections taken to different heights and derived from three-dimensional muqarnas geometry. Layers can be described as the third dimension of the muqarnas geometry in a two-dimensional pattern. Özdural (1991), uses the term "course" and makes explanations in relation to the construction and design process of muqarnas elements. Özdural (1991), also uses the term "outline" to express the contour of the courses. According to Özdural (1991), muqarnas are designed in two-dimensional plan levels and afterwards they are projected onto the third dimension. Quoting Özdural (1991): "All the decisions are taken on the plan level; three-dimensional massing is created simply by introducing course heights." Therefore, post-construction, layer lines embedded in 2D muqarnas patterns remain perceivable.

- String: In computer science, a string is any finite sequence of characters (i.e., letters, numbers, and symbols). An important characteristic of each string is the number of characters in it, also known as its length. In this study, a string refers to the group of elements encoded in letters and arranged sequentially between two layer lines.

- Level of detail: By dividing the shapes (polygons) into sub-parts and combining the subdivided parts, it is possible to create patterns with different levels of detail while using the same layout. For these detailing processes, various concepts are used such as "subdivision" (Cromwell, 2009), "inflation" of kites and darts of the Penrose tiles (Penrose, 1979) and "inflation"of Girih tiles (Lu \& Steinhardt, 2007). A matrix-based transition method to justify tectonic relations was illustrated by Özdural (1991). Özdural (1991) used three different levels which can be superimposed: (i) grid system, (ii) schematic plan, and (iii) plan drawing showing muqarnas elements. As a result, in this study, "level of detail" refers to the transition between different two-dimensional patterns created through subdivision operations.

\section{METHOD}

Shannon's information entropy was used as a method in this study due to its compatibility for contentindependent entropy measurements. In other words, as being a content-independent measurement, it is possible to adopt entropy measurements to any selected content. Previous studies in the literature recoded images or drawings to perform entropy calculations (Krampen, 1997; Stamps, 2004; Güzelci \& Şener, 2018). Coding the different images and drawings in the same language is essential for achieving meaningful, precise and consistent entropy measurements and comparisons. In this study muqarnas patterns are chosen as a source of information. As a case study, one of the finest examples of Seljuk medreses, two-dimensional projection of the entrance portal of Buruciye Medrese in Sivas was studied. To calculate the amount of information in the muqarnas pattern, two dimensional projected drawings of Buruciye Medrese produced by Özdural (1991) were used. Özdural's (1991) muqarnas pattern drawings include three level of details: (i) grid system, (ii) schematic plan, and (iii) plan drawing. These drawings are redrawn on a computer aided drawing tool, AutoCAD 2018. Afterwards, the drawings are imported to Rhino 6.0 to process the shape detection and entropy measurement algorithms.

Shape detection algorithm determines similar and different shapes within a set of shapes. This determination is based on taking each closed polygon as a separate shape. Following this operation, the area and perimeter values of each shape is calculated, listed and sorted. Therefore, each shape type were represented with a different letter. The outcomes of the shape detection process are used as input for entropy measurement algorithm. Shape entropy was used as the calculation method, which was 
The Turkish Online Journal of Design, Art and Communication - TOJDAC

ISSN: 2146-5193, April 2019 Volume 9 Issue 2, p. 191-201

introduced and used in a variety of ways in previous studies (Crompton, 2012; Stamps, 2012). To measure the shape entropy values, shape types, the total number of shapes and the repetition numbers of each shape type are used. In this study, the entropy measurement operations are executed under three main methods: (i) entire patterns as a shape space, (ii) single layers as individual shape spaces, (iii) single layers in entire patterns.

\section{Information Entropy}

To measure the disorder in information, as different from the approach to entropy concept used in physics, Claude Shannon rediscovered the concept of entropy, in the scope of information theory in 1948 (Crompton, 2012; Shannon, 1948). Information theory states that the amount of information calculated by taking the logarithmic value of the number of available alternatives can be transmitted as a message. When an information source can generate 8 alternative messages and the probability of these alternative messages occurrence is equal then the entropy value is at its highest; therefore, 8 messages are expressed as $2^{3}$ and according to the mathematical operation of $\log _{2} 8=3$, the entropy value of the information source is calculated as 3 bits (Weaver, 1953). In the basic entropy equation; $\mathrm{H}$ denotes the entropy value calculated for a factor; furthermore, "p" defines the probability of occurrence of a factor (Stamps, 2004; Crompton, 2012). For instance, a string made of 10 letters was created to describe the entropy calculation with basic equation given in Figure 2 . In the ABBCCCDDDD letter string, there is one count "A", two counts "B", three count of " $C$ ", and four count of " $D$ ". In this case, frequencies of the letters in the string are $1 / 10,2 / 10,3 / 10$, and 4/10 respectively. After making individual entropy calculation based on probabilities of each letter type, the entropy value of each letter $(0.332193,0.464386,0.52109,0.528771$ bits $)$ was summed and the overall entropy value $(\mathrm{H}=1.84644$ bits $)$ of the string was obtained.

$$
H_{\text {factor }}=-\sum_{i=1}^{\text {nlevels }} p_{i} \log _{2} p_{i}
$$

Figure 2: The basic entropy equation (Stamps, 2004)

The two-dimensional shapes that form the muqarnas can be perceived easily through two-dimensional patterns. The muqarnas patterns examined under the study are composed of repeating two dimensional shapes such as squares, triangles, trapezoids etc. Shapes without overlaps or intersections are one of the main characteristics of muqarnas patterns. To calculate the complexity of muqarnas patterns, we have reinterpreted the shape entropy calculation methods used in previous studies. Previous studies have used shape factors to calculate the entropy of LEGO models of well-known buildings (Crompton, 2012) and three-dimensional abstract compositions created with LEGO models (Stamps, 2012), whereas, building's floor plans (Güzelci, 2017; Güzelci \& Şener, 2018) were reinterpreted in this study to calculate the entropy in two-dimensional muqarnas patterns where each element of the whole were represented with letters.

\section{Method 1: Shape Entropy Calculation for Entire Shape Space}

In Method 1, the entire muqarnas pattern was considered as a shape space. In this experiment, to calculate the shape entropy, the muqarnas pattern was observed as a whole created from discrete parts, as well as the types of elements and their counts are identified. In the sample shape entropy calculation in Method 1 based on a low level of detail "grid system" muqarnas pattern, first, all present shapes were represented with letters (Figure 3); then, all muqarnas elements were converted into a string made of 72 letters. Once the letters were grouped, it was observed that the muqarnas patterns included letters of $\mathrm{A}, \mathrm{B}$, and $\mathrm{C}$ and that there were 32,32 , and 8 of these shapes, respectively. By inserting the ratio of the repeating numbers of all elements to the total number of elements into the basic entropy equation, shape entropy values for each shape were calculated. Further, multiplying the entropy value 
of 1.169925 per selected shape type (A) by the count of repetition of 32, the entropy produced by the shape type was calculated as 37.4376 bits. Through the process of summing the results of the multiplications for each shape type, the overall shape entropy was calculated as 100.2346 bits. Finally, by dividing the overall shape entropy value by the total count of shapes, 72 , the average shape entropy of the "grid system" muqarnas pattern was calculated as 1.392147 bits (Figure 4).

The steps used in Method 1 were then applied to the "schematic plan" of the muqarnas pattern, however, this time, a medium level of detail was investigated (Figure 5). As a result, shape entropy of the entire pattern consisted of 168 elements and 19 shape types were calculated. The findings were as follows: an overall shape entropy value of 620.5609998 bits and an average shape entropy value of 3.693815 bits were observed in the investigated "schematic plan" (Figure 6). Further, the procedures used in Method 1 were then applied to the "plan drawing" with a high level of detail was investigated (Figure 7). As a result, shape entropy of the entire pattern consisted of 536 elements and 23 shape types were identified. The findings were as follows: an overall shape entropy value of 2020.222732 bits and an average shape entropy value of 3.769072 bits were observed in the investigated "plan drawing" (Figure 8).

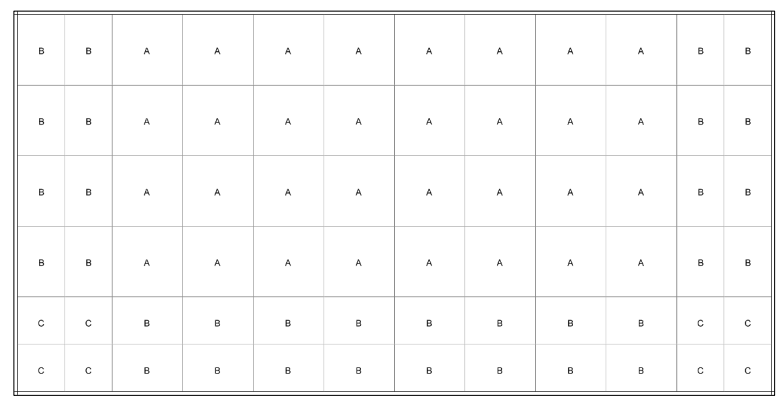

Figure 3: "Grid system" representation of muqarnas pattern on a low level of detail

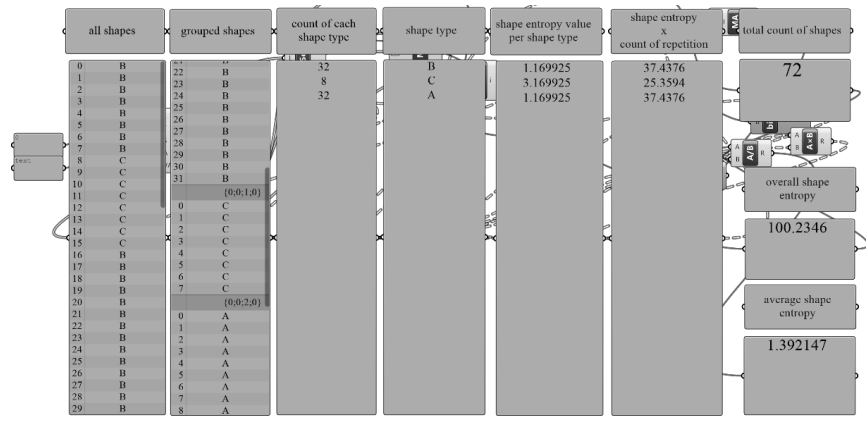

Figure 4: Shape entropy calculation of Muqarnas pattern illustrated in Figure 3

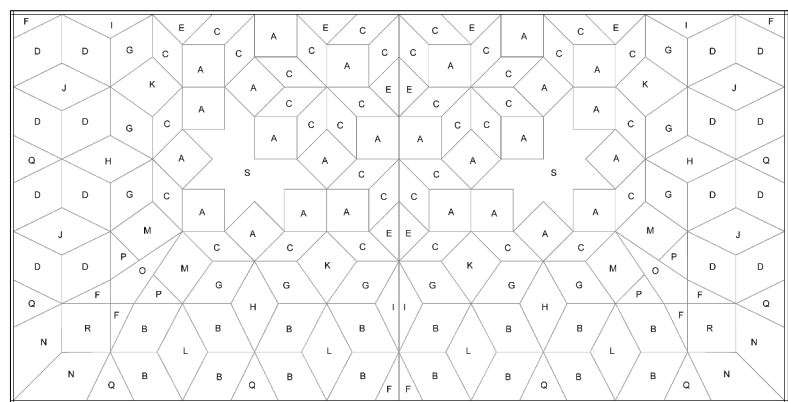

Figure 5: "Schematic plan" representation of muqarnas pattern on a medium level of detail 


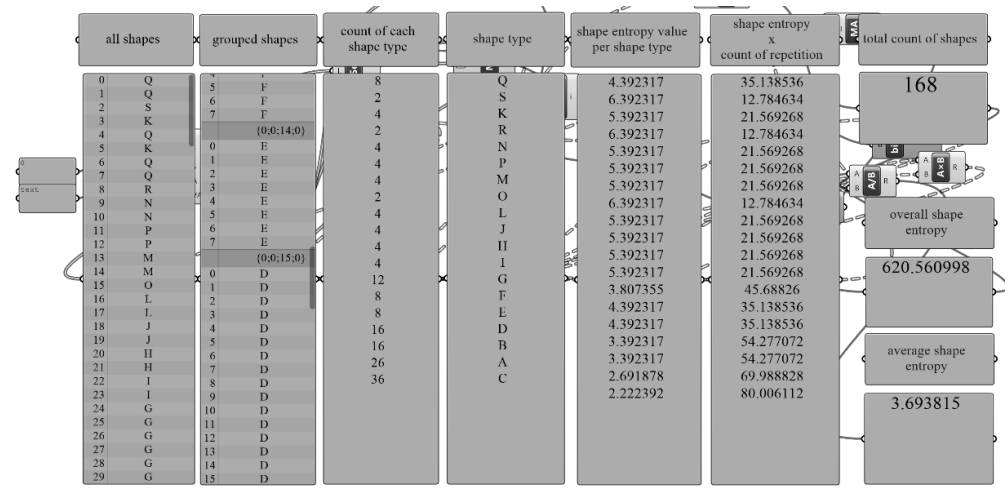

Figure 6: Shape entropy calculation of Muqarnas pattern illustrated in Figure 5

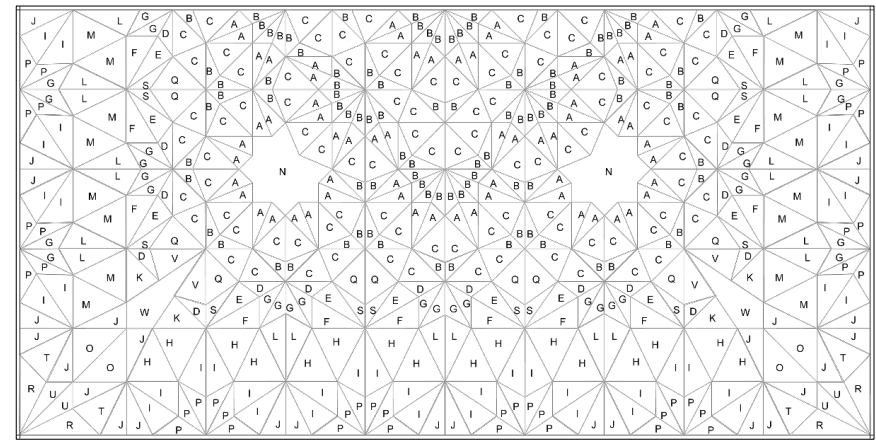

Figure 7: "Plan drawing" representation of muqarnas pattern on a medium level of detail

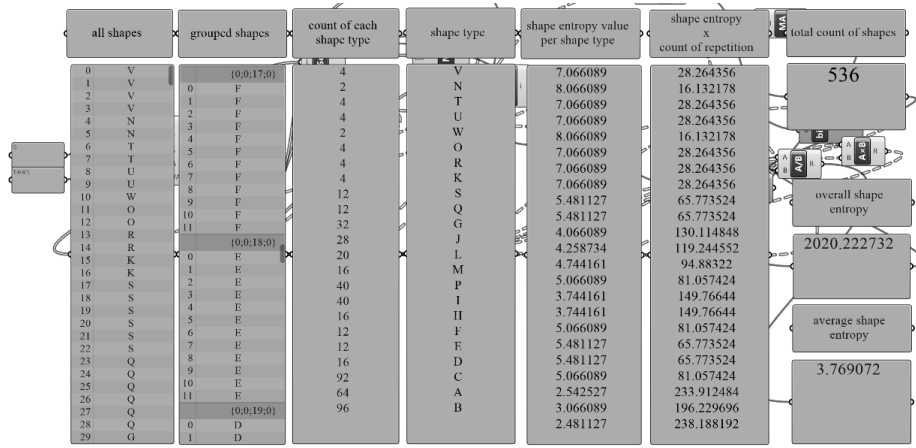

Figure 8: Shape entropy calculation of Muqarnas pattern illustrated in Figure 7

\section{Method 2: Shape Entropy Calculation for Each Layer Individually}

The readability of the elements by sequential alignment (juxtaposition) as a string is a requirement; in the case of muqarnas pattern, it is possible to juxtapose the elements by using layer lines. Juxtaposition makes it possible to list the elements, detect repetitions and calculate frequency values of these repetitions. As illustrated in Figure 9, Buruciye Medrese's muqarnas pattern consists of 11 layers and 10 layer lines. The strings $0,1,2,4,5,6,8$ containing the sequence of the elements in the layers of muqarnas have the characteristics of a continuous string. The nature of continuous strings involves the sharing of edges, as illustrated in Figure 9. On the contrary, strings 3, 7, 9 and 10 are identified as broken strings due to a lack of shared edges; broken strings carry the presence of shared corners (Figure 9). 


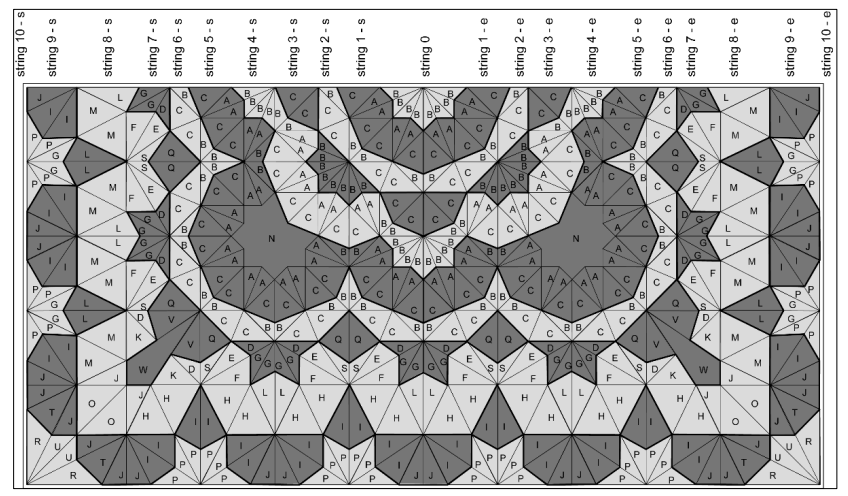

Figure 9: Layer-based representation of muqarnas pattern elements in strings

Table 1. One-dimensional array of continuous and broken strings

\begin{tabular}{|l|l|}
\hline $\begin{array}{l}\text { String } \\
\text { Name }\end{array}$ & Layers as 1 dimensional array \\
\hline String 0 & BBBBBBBB \\
\hline String 1 & CAACCAACCAACCAAC \\
\hline String 2 & BCCBBCCBBCCBBCCB \\
\hline String 3 & CC-BBBBBBBB-CCCC-BBBBBBBB-CC \\
\hline String 4 & BBBBBBAACCAACCAACCAABBBBBBBBBBBBAACCAACCAACCAABBBBBB \\
\hline String 5 & $\begin{array}{l}\text { CAACCAABBAACCAACCAACCAACCAACCAABBAACCAACCAACCAABBAACCAACCAACCA } \\
\text { ACCAACCAABBAACCAAC-N-N }\end{array}$ \\
\hline String 6 & BCCBBBBCCBBCCBBCCBBCCBBBBCCBBCCBBBBCCBBCCBBCCBBCCBBBBCCB \\
\hline String 7 & GGD-QQ-DGGGGD-QVWVQ-DGGGGD-QQ-DGGGGD-QQ-DGGGGD-QVWVQ-DGGGGD-QQ-DGG \\
\hline String 8 & $\begin{array}{l}\text { LMMFESSEFMMLLMMFESDKMMJOOJHHKDSEFHHLLHHFESSEFHHLLHHFESSEFHHLLHHFESD } \\
\text { KHHJOOJMMKDSEFMMLLMMFESSEFMML }\end{array}$ \\
\hline String 9 & JII-LL-IIJJII-LL-IIJJTJ-JTJJII-II-IIJJII-II-IIJJII-II-IIJJII-II-IIJJTJ-JTJJII-LL-IIJJII-LL-IIJ \\
\hline String 10 & PPGGPP-PPGGPP-RUUR-PPPPPP-PPPPPP-PPPPPP-PPPPPP-RUUR-PPGGPP-PPGGPP \\
\hline
\end{tabular}

In Experiment 2, each string between layer lines are considered as individual shape spaces. In this case, entropy value of each element is calculated by finding the frequency of repetition of the element in the individual string where each element is located. In a case where a string is composed of the repetition of a single element type, there lacks diversity and thus the entropy value of the string is calculated as zero. According to information theory, in situations where all units are different or have equal occurrence probability, the entropy assumes its maximum value. On the contrary, if all the units are the same, the entropy value is calculated as zero. For example, because all elements of String 0 are B's, the entropy value is calculated as zero. Furthermore, since String 1 includes only A's and C's and these two elements have been observed to repeat an equal amount of times, therefore, the entropy value is calculated as 1 bit (Table 2). Table 2 describes the results of the calculations based in Method 2 , which details the unit numbers and number of element types, and the calculated entropy values using the information in Figure 9 and Table 1.

Table 2. Individual shape entropy calculation of each string

\begin{tabular}{|c|c|c|c|}
\hline String Name & Number of Units & Number of Types & Calculated Entropy Values (bits) \\
\hline String 0 & 8 & 1 & 0 \\
\hline String 1 & 16 & 2 & 1 \\
\hline String 2 & 16 & 2 & 1 \\
\hline String 3 & 24 & 2 & 0,918296 \\
\hline
\end{tabular}


The Turkish Online Journal of Design, Art and Communication - TOJDAC

ISSN: 2146-5193, April 2019 Volume 9 Issue 2, p. 191-201

\begin{tabular}{|c|c|c|c|}
\hline String 4 & 52 & 3 & 1,526235 \\
\hline String 5 & 82 & 4 & 1,493197 \\
\hline String 6 & 56 & 2 & 0,985228 \\
\hline String 7 & 54 & 5 & 1,938625 \\
\hline String 8 & 96 & 10 & 3,125815 \\
\hline String 9 & 76 & 4 & 1,577977 \\
\hline String 10 & 56 & 4 & 1,291692 \\
\hline
\end{tabular}

\section{Method 3: Shape Entropy Calculation for Each Layer in the Entire Shape Space}

Method 3 calculates the entropy values of each string individually. However, when calculating the entropy values of each element in different strings, Method 3 differentiates in the sense that frequencies of shapes are calculated by searching the entire shape space, rather than considering each string as individual shape spaces. As a result of this, Experiment 3 uses the entropy values calculated per shape as a result of Experiment 1 (Figure 8), while calculating the entropy value of each string. By multiplying the entropy values per shape and count of repetition, the shape entropy of the selected shape type is calculated in that string. In Experiment 3, the same procedure is repeated for each shape type. Finally, by summing the multiplications, the overall shape entropy of the string is calculated (Table 3).

Table 3. Shape entropy calculation for each layer

\begin{tabular}{|c|c|c|c|}
\hline String Name & $\begin{array}{c}\text { Number of } \\
\text { Units }\end{array}$ & Calculated Entropy Value (bits) & Overall Shape Entropy (bits) \\
\hline String 0 & 8 & For B: $8 \times 2,481127=19,849016$ bits & String 0 Total: 19,849016 bits \\
\hline String 1 & 16 & $\begin{array}{l}\text { For A's: } 8 \text { × 3,066089 }=24,528712 \text { bits } \\
\text { For C's: } 8 \text { x 2,542527 }=20,340216 \text { bits }\end{array}$ & String 1 Total: 44,868928 bits \\
\hline String 2 & 16 & $\begin{array}{l}\text { For B's: } 8 \times 2,481127=19,849016 \text { bits } \\
\text { For C's: } 8 \times 2,542527=20,340216 \text { bits }\end{array}$ & String 2 Total: 40,189232 bits \\
\hline String 3 & 24 & $\begin{array}{l}\text { For B's: } 16 \text { x 2,481127 = 39,698032 bits } \\
\text { For C's: } 8 \text { x 2,542527 =20,340216 bits }\end{array}$ & String 3 Total: 60,038248 bits \\
\hline String 4 & 52 & $\begin{array}{l}\text { For B's: } 24 \times 2,481127=59,547048 \text { bits } \\
\text { For A's: } 16 \times 3.066089=49,057424 \text { bits } \\
\text { For C's: } 12 \times 2,542527=30,510324 \text { bits }\end{array}$ & String 4 Total: 139,114796 bits \\
\hline String 5 & 82 & $\begin{array}{l}\text { For B's: } 8 \text { X 2,481127 = 19,849016 } \\
\text { For A's: } 40 \text { X 3.066089=122,643560 } \\
\text { For C's: } 32 \text { X 2,542527 = 81,360864 } \\
\text { For N's: } 2 \text { X 8,066089=16,132178 }\end{array}$ & String 5 Total: 239,985618 bits \\
\hline String 6 & 56 & $\begin{array}{l}\text { For C's: } 32 \text { X 2,481127 = 79,396064 bits } \\
\text { For B's: } 24 \text { X 2,542527 = 61,020648 bits }\end{array}$ & String 6 Total: 140,416712 bits \\
\hline String 7 & 54 & $\begin{array}{l}\text { For V's: } 4 \text { × 7,066089 }=28,264356 \text { bits } \\
\text { For W's } 2 \times 8,066089=16,132178 \text { bits } \\
\text { For Q's: } 12 \times 5,481127=65,773525 \text { bits } \\
\text { For G's: } 24 \times 4,066089=97,586136 \text { bits } \\
\text { For D's: } 12 \times 5,066089=60,793068 \text { bits }\end{array}$ & String 7 Total: 268,549262 bits \\
\hline String 8 & 96 & 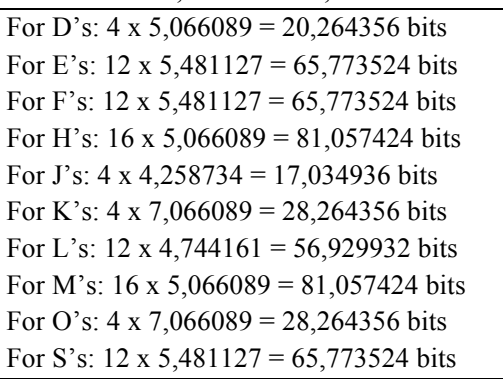 & String 8 Total: 510,193356 bits \\
\hline String 9 & 76 & $\begin{array}{l}\text { For I's: } 40 \text { x 3,744161 = 149,766440 bits } \\
\text { For J's: } 24 \text { x 4,258734 = 102,209616 bits } \\
\text { For L's: } 8 \text { x 4,744161 = 37,953288 bits }\end{array}$ & String 9 Total: 318,193700 bits \\
\hline
\end{tabular}

Submit Date: 10.01.2019, Acceptance Date: 25.03.2019, DOI NO: 10.7456/10902100/011

Research Article - This article was checked by Turnitin

Copyright (C) The Turkish Online Journal of Design, Art and Communication 
The Turkish Online Journal of Design, Art and Communication - TOJDAC

ISSN: 2146-5193, April 2019 Volume 9 Issue 2, p. 191-201

\begin{tabular}{|c|c|c|c|}
\hline & & For T's: 4 x 7,066089=28,264356 bits & \\
\hline String 10 & 56 & $\begin{array}{l}\text { For G's: } 8 \text { × 4,066089 = 32,528712 bits } \\
\text { For P's: } 40 \text { × 3,744161 = 149,766440 bits } \\
\text { For R's: } 4 \text { × 7,066089=28,264356 bits } \\
\text { For U's: } 4 \text { × 7,066089 =28,264356 bits }\end{array}$ & String 10 Total: 238,823864 bits \\
\hline
\end{tabular}

Table 3 describes the results of the calculations based in Method 3, which details the unit numbers, calculated entropy values of each shape type and the overall shape entropy of each string using the outputs in Figure 9 and Table 1.

\section{RESULTS AND DISCUSSION}

Within the scope of the study, three entropy-based methods were used to calculate the entropy values of the muqarnas pattern located in the portal of the Buruciye Medrese, which was built in the Seljuk Period in Sivas. Method 1 was applied to the pattern with three levels of detail examined in the study. As a result, it was observed that increasing levels of detail of pattern increases the average and overall shape entropy. The main reason for the rise of the overall entropy value is the increase in the number of parts and the shape type due to the subdivisions operation done to make a transition between different detail levels (Figure 3-8). As a result of the study, it is observed that calculated entropy value changes when the muqarnas pattern have different levels of detail. Method 2 and Method 3 have been applied only to the "plan drawing" which is the muqarnas pattern with high level of detail. In Method 2 , when each string is considered to be an individual shape space and the overall entropy is calculated for each string, it is observed that strings consist of many elements have very low entropy (between 0 $1 \mathrm{bit}$ ) due to monotony. Furthermore, it was found that the rise of the entropy value of the strings was not a direct positive relation to the count of elements or the number of element types in the string. In Method 3, the total entropy values of each string are calculated by taking the entire pattern as a shape space. As a result of the application of Method 3, it was seen that the strings having the same number of elements, element type and uniformity had different overall entropies. The reason for this is that the elements within the string have different frequencies in the entire pattern. Similar to results of experiments within Method 2, it was found that the entropy increase of the strings was not a direct positive relation to the count of elements or the number of element types in the string. In addition, it was observed that the entropy values of the discrete layers differed from each other. The proposed entropy calculation method is generic and has the ability to calculate the complexity levels of different muqarnas patterns. It is possible to apply the proposed method into different contexts. For example, this method can be used to determine the complexity level of muqarnas belonging to a particular region, period, architect or artisan. Apart from this, in future studies it is aimed to improve the proposed method towards a pattern generator based on predefined complexity level by employing machine learning algorithms.

\section{REFERENCES}

Alaçam, S., Güzelci, O. Z., Gürer, E., \& Bacınoğlu, S. Z. (2017). Reconnoitring computational potentials of the vault-like forms: Thinking aloud on muqarnas tectonics. International Journal of Architectural Computing, 15(4), 285-303.

Al Kashi, G.A.D.N. (1977). Key of arithmetics (ed Nablusi N, Arabic edition). Damascus: University of Damascus Press.

Arik, M., \& Sancak, M. (2007). Turkish-Islamic art and Penrose tilings. Balkan Physics Letters, 15(1), $1-12$

Arnheim, R. (1971). Art and Entropy: An Essay on Disorder and Order. Berkeley: University of California Press.

Crompton, A. (2012). The entropy of LEGO ${ }^{\circledR}$. Environment and Planning B: Planning and Design, 39(1), 174-182. 
The Turkish Online Journal of Design, Art and Communication - TOJDAC

ISSN: 2146-5193, April 2019 Volume 9 Issue 2, p. 191-201

Cromwell, P. R. (2009). The search for quasi-periodicity in Islamic 5-fold ornament. The Mathematical Intelligencer, 31(1), 36-56.

Dold-Samplonius, Y., \& Harmsen, S. L. (2005). The muqarnas plate found at Takht-i Sulayman: a new interpretation. Muqarnas, 22, 85-94.

Dold-Samplonius, Y., \& Harmsen, S. L. (2015). Muqarnas: Construction and Reconstruction. In Architecture and Mathematics from Antiquity to the Future (pp. 709-719). Birkhäuser, Cham.

Güzelci, O. Z. (2017). Investigating the role of Entropy in Design Evaluation Process: A Case Study on Municipality Buildings. In G. Çagdaş, M. Özkar, L. F. Gül, E. Gürer (Eds.), Proceedings of 17th International Conference, CAAD Futures 2017: Future Trajectories of Computation in Design (pp. 211-224). Turkey: Istanbul Technical University.

Güzelci, O. Z., \& Şener, S. M. (2018). A design evaluation model for architectural competitions: Measuring entropy of multiple factors in the case of municipality buildings. $A \mid Z$ ITU Journal of the Faculty of Architecture, 15(1), 107-122.

Harmsen, S. (2006). Algorithmic computer reconstructions of stalactite vaults-muqarnas-in Islamic architecture. Doctoral Dissertation, Heidelberg University, Heidelberg.

Hensel, M. (2008). Performance Orientated Design Precursors and Potentials. Architectural design, 78(2), 48-53.

Krampen, M. (1979). Meaning in the urban environment. London: Pion Limited.

Lu, P. J., \& Steinhardt, P. J. (2007). Decagonal and quasi-crystalline tilings in medieval Islamic architecture. science, 315(5815), 1106-1110.

Notkin, I. I. (1994). Decoding sixteenth-century muqarnas drawings. Muqarnas Online, 12(1), 148171.

Özdural, A. (1990). Giyaseddin Jemshid el-Kashi and Stalactites. Middle East Technical University, Journal of the Faculty of Architecture, 10(1-2), 31-49.

Özdural, A. (1991). An analysis of the geometry of stalactites: Buruciye Medrese in Sivas. Middle East Technical University Journal of the Faculty of Architecture, 11(1-2), 57-71.

Özdural, A. (2000). Mathematics and arts: Connections between theory and practice in the medieval Islamic world. Historia mathematica, 27(2), 171-201.

Penrose, R. (1979). Pentaplexity a class of non-periodic tilings of the plane. The mathematical intelligencer, 2(1), 32-37.

Salingaros, N. A. (1999). Architecture, patterns, and mathematics. Nexus Network Journal, 1(1-2), 7586.

Salingaros, N. A. (2014). Complexity in architecture and design. Oz, 36(1), 18-25.

Shannon, C. E. (1948). A Mathematical Theory of Communication. Bell System Technical Journal, 27(3), 379-423.

Stamps III, A. E. (1998). Complexity of architectural silhouettes: from vague impressions to definite design features. Perceptual and motor skills, 87(3_suppl), 1407-1417.

Stamps III, A. E. (2004). Entropy and visual diversity in the environment. Journal of Architectural and Planning Research, 21(3), 239-256.

Stamps III, A. E. (2012). Commentary on the entropy of LEGO®. Environment and Planning B: Planning and Design, 39(1), 183-187.

Standish, R. K. (2008). Concept and definition of complexity. In Intelligent complex adaptive systems (pp. 105-124). IGI Global.

Url-1. https://kulturportali.gov.tr/turkiye/sivas/gezilecekyer/burucye-medreses

Weaver, W. (1953). Recent contributions to the mathematical theory of communication. ETC: a review of general semantics, 10(4), 261-281.

Submit Date: 10.01.2019, Acceptance Date: 25.03.2019, DOI NO: 10.7456/10902100/011

Research Article - This article was checked by Turnitin 